\title{
副耳下腺より発生した多形腺腫例
}

\author{
萩池 洋子・赤木 博文・木村 宣彦・江口 元治 \\ 小坂 道也・小川 晃弘・西㟝 和則
}

\section{A Case of Pleomorphic Adenoma Arising from Accessory Parotid Gland}

\author{
Yoko Hagiike, Hirofumi Akagi, Nobuhiko Kimura, Motoharu Eguchi, \\ Michiya Kosaka, Teruhiro Ogawa and Kazunori Nishizaki \\ (Okayama University)
}

\begin{abstract}
Although accessory parotid glands are found in $20-70 \%$ of normal persons, tumors arising from accessory parotid glands are reportedly rare. We demonstrated a case of pleomorphic adenoma arising from the accessory parotid gland. A 43-year-old female was brought to our hospital with a left cheek mass. Imaging demonstrated an oval-shaped tumor on the masseter muscle located in the mid-portion of her cheek, without any evidence of relationship with the parotid gland. Surgically the tumor was completely removed through a transparotid approach and pathologically diagnosed as pleomorphic adenoma.

Reports of the incidence of accessory parotid glands in humans are inconsistent, so we investigated the various reported values. We concluded that over $55 \%$ of normal people have accessory parotid glands in their left or right cheeks.
\end{abstract}

Key words : pleomorphic adenoma, accessory parotid gland, cheek mass, incidence

はじめに

副耳下腺は，耳下腺本体と解剖学的に分離した異所性 唾液腺の一つであり，その出現する割合は健康成人にお いて約 $20 \sim 70 \%$ と，文献によりさまざまな值が報告さ れている1) 12). 日常診療でこの存在を認識することは あまりないが，腫瘍や炎症性疾患の原因となっている場 合には臨床的な問題となりらる．副耳下腺由来の腫瘍の 報告は少なく, 全耳下腺腫瘍のうち $1 \sim 7 \%$ 程度の比較 的まれな疾患である13) 15). 今回われわれは，副耳下腺 に発生した多形腺腫例を副耳下腺の正常人における出現 率など文献的考察を加えて報告する。

\section{症例}

患者： 43 歳, 女性.

主訴：左煩部腫瘤.
既往歴：特記すべきことなし．

家族歴：父 胃癌, 母 メニエール病・高血圧, 長男 喘息. 他に腫瘍性病変の家族歴なし。

現病歷 : 平成 7 年 4 月頃から左煩部腫瘤を自覚し, 同 月 27 日近医内科を受診した。 CT にて皮下腫瘤を認めた ため，5月 16 日当科に紹介受診となった。

初診時所見：左煩部に約 $1 \mathrm{~cm}$ の弾性硬, 可動性良好な 腫瘤を触知した。顔面神経麻痺は認めなかった。

経過 : 局所所見，CT 所見より良性腫瘍を疑ったが，小 指頭大と小さく患者も手術を希望しなかったため, 月 1 回の外来通院で経過観察となった. 初診後4カ月は症状 や腫瘤の大きさに変化は認めなかったが, その後は患者 の判断で受診が中断した. 平成 10 年頃より腫瘤が徐々に 増大し, 平成 12 年 4 月 26 日当科に再受診となった。

再受診時所見 : 初診時に認めた腫瘤と同部に約 $4 \times$ 


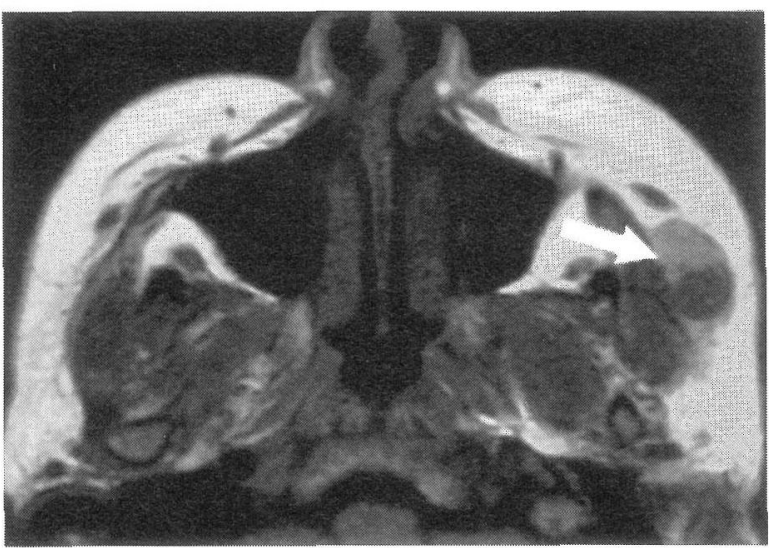

図 1 MRI 所見（T1 強調像）

咬筋の外側に楕円形の境界明瞭な腫瘍陰影を認める（矢 印)。

$3.5 \mathrm{~cm}$ の可動性良好な腫瘤を触知した。開口障害, 顔面 神経麻痺は認めなかった。

画像所見: CT 上, 左咬筋上に約 $3 \times 2 \mathrm{~cm}$ の境界明膫, 辺縁整で内部が一部造影される卵形腫瘍陰影を認めた。 MRIではCTと同部にT1強調像で低信号 (一部等信号) (図 1)，T2 強調像で高信号（一部低信号）を呈する境界明瞭 な腫怚陰影を認めた。耳下腺との連続性は認めなかった。 Tcシンチグラムでは異常集積像や欠損像は認めなかっ た。

以上より副耳下腺由来の良性腫瘍を疑い，入院の上平 成 12 年 6 月 22 日手術を施行した。

手術所見:耳下腺手術に準じ $S$ 字状の皮膚切開を加え， 煩部皮弁を腫瘍の前縁まで挙上した。耳下腺前縁で顔面 神経を確認することが困難であったため, 定型通り本幹 を確認した上で末梢へ剥離を進め，煩骨枝，煩筋枝を露 出させた。腫瘤は耳下腺前縁と連続性はなく，㚘骨枝の 内側で頛筋枝に接するように存在していたが癒着はな く，神経を保存しながら腫瘤を一塊にして摘出した。摘 出腫瘤の大きさは約 $3.0 \times 2.0 \mathrm{~cm}$ で, 一部囊胞を伴って いた（図 2)。

病理組織所見：円形細胞が充実性に增殖し，小管腔を 形成する部分や軟骨腫様形態をとる部分の混在が認めら れ，多形腺腫と診断した (図 3)。周囲に正常耳下腺組織 を認めた。

以上より副耳下腺に発生した多形腺腫と診断した。

術後経過: 術直後は 40 点法で 34 点の左顔面神経麻痺 を認めたが，約 1カ月で回復した。その後再発や唾液瘦

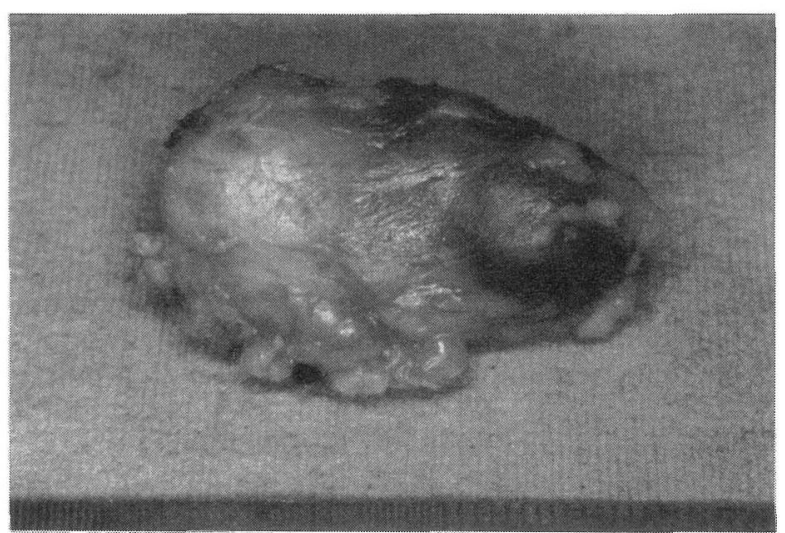

図 2 摘出標本

一部囊胞を伴っている。

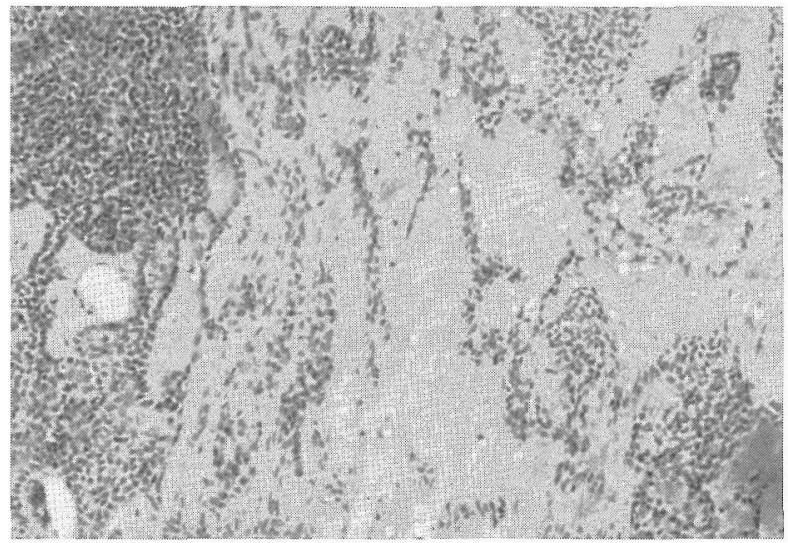

図 3 病理組織所見 $(\mathrm{HE}$ 染色, $\times 200)$

円形細胞が増殖し，小管腔や軟骨腫様の形態をとる部分 が混在しており, 多形腺腫と診断した。

等の合併症は認めず，経過は良好である.

\section{考察}

1. 副耳下腺の出現率

われわれが日常診療において副耳下腺を認識するの は，耳下腺造影など耳下腺病変の画像診断に際して，同 時に描出される場合がほとんどだと思われる。文献1) 12) では副耳下腺の出現率は $20 ７ 0 \%$ とまれな存在ではな いとされているが,この值は誤差とするには幅が大きく， 出現率について文献をさらに詳細に検討してみた。

副耳下腺の出現率について，詳細な定義をしているも のはないが，本報告では 1 個体の人間に少なくとも左右 いずれかに 1 つ以上副耳下腺が認められる割合として検 
表 1 副耳下腺の出現率

\begin{tabular}{|c|c|c|c|c|c|c|c|}
\hline 報告者 & 年 & 検索方法 & 症例数 & $\begin{array}{l}\text { 出現率 (\%) } \\
\text { (症例数) }\end{array}$ & $\begin{array}{c}\text { 両側 (\%) } \\
\text { (症例数) }\end{array}$ & $\begin{array}{l}\text { 右 (\%) } \\
\text { (症例数) }\end{array}$ & $\begin{array}{l}\text { 左 (\%) } \\
\text { (症例数) }\end{array}$ \\
\hline 小川11) & 1918 & 剖検 & 41 & $36.6(15 / 41)$ & $14.6(6 / 41)$ & $19.5(8 / 41)$ & $26.8(11 / 41)$ \\
\hline 青ら2) & 1956 & 剖検 & 44 (88 側) & $35.2(31 / 88)$ & & $40.9(18 / 44)$ & $29.5(13 / 44)$ \\
\hline 布施3)（北村 ${ }^{4) 5)} 1956 ）$ & 1957 & 耳下腺造影 & 200 & $23.5(47 / 200)$ & & & \\
\hline 石島6) & 1958 & 剖検 & 76 (152 側) & 25.4 & & 30.6 & 25.4 \\
\hline Frommer ${ }^{7)}$ & 1977 & 剖検 & 96 & $20.8(20 / 96)$ & & & \\
\hline 藤 $ら^{8)}$ & 1984 & 剖検 & 32 & $68.8(22 / 32)$ & 15. $6(5 / 32)$ & $18.8(6 / 32)$ & $34.4(11 / 32)$ \\
\hline 藤ら ${ }^{9)}$ & 1988 & 剖検 & 123 & $61.0(75 / 123)$ & $14.6(18 / 123)$ & $35.8(44 / 123)$ & $39.8 \quad(49 / 123)$ \\
\hline Toh $5^{10)}$ & 1993 & 剖検 & 228 & $56.1(128 / 228)$ & 14. $0(32 / 228)$ & $19.3(44 / 228)$ & $22.8(52 / 228)$ \\
\hline 遠藤ら & 1997 & 耳下腺造影 & 63 & $27.0(17 / 63)$ & & & \\
\hline
\end{tabular}

討した。われわれが渉猟し得た範囲では，1918 年の小 川11) の報告を最初にいくつか検討されているが，それら の文献をもとに表にまとめた（表 1)。なお布施3) の報告 は, 北村 45) の報告を補遺といら形でまとめたもので, 検 討症例, 検討方法, 分類など同一と考えられたため, 症 例数を追加し詳細に表記してある布施引の報告を用いた。 また青ら ${ }^{2)}$ と石島 ${ }^{6)}$ は同一教室で, 指導教授 (上條 $\left.{ }^{12)}\right)$, 発表年代もほぼ同じであるが, 副耳下腺の形態統計など より検討症例は異なると考えた. 藤ら $\left.{ }^{8)} \sim 10\right)$ は症例数を 増やしながら検討を重ね, 報告を順次行っているため, 検討症例が重なっているものもあると思われた.

副耳下腺は, 解剖学的に耳下腺本体と分離している組 織であり, 出現率を検討する際, 本腺と接しているもの は除外されている7). しかし布施 ${ }^{3)}\left(\right.$ 北村 $^{4) 5)}$ ) は導管の 分岐する位置により副耳下腺を分類しており，副腺が認 められたとする症例数 (96 例) から出現率を計算すると 48.0\%（96/200）となるが，これには耳下腺と1つの被 膜に包まれているものも含んでいる，そのため定義に 従って症例を選び，23.5\%とした．また高い率を報告し ている藤ら ${ }^{8)}$ 10) は, 耳下腺前縁と副耳下腺が連続性が なければ，接していても副耳下腺としており，これが他 者との差と思われる. また藤ら ${ }^{9)}$ は, 他者が米粒様の小 腺を見落としている可能性を示唆しており, 出現率の差 の一因になっていると考察している.

検討方法では，剖検によるものと耳下腺造影によるも のがあった．青ら ${ }^{2)}$ は，耳下腺造影による場合の方が剖 検例より高率に出現することが多いと述べているが，今 回の検討ではそういった傾向は認めなかった. また，耳
下腺造影像の読影に際して副耳下腺の腺陰影は薄く, 耳 下腺前縁でステノン氏管に沿って前方へ突出している前 突起との区別が困難なことがあり ${ }^{16)}$, 導管の存在む認め にくい14)ことから, 逆に耳下腺造影のみでは見落とす可 能性があると考えた。

各報告で検討されている症例数は約 $40 \sim 200$ 例であ り, 副耳下腺を統計学的処理するには症例数が足りない と考えられるものもあった．また，左右それぞれについ て検討した報告も認めた. 左右への出現率の差異はない と思われたが，必ずしも両側性に認められるものではな いようであった。両側性の出現率は約 $15 \%$ であり, 片側 性のものもかなりあると思われる。 そのため 1 症例 1 側 のみの検討では, 他側の副耳下腺を見落とす可能性があ り, 副耳下腺の出現率は低くなるであろう。また 1 症例 両側を検討しているものでも，出現率を計算する際に, 1 症例を左右それぞれで2症例として算出しているもの226) があった。この計算の方法では, 結局, 前述の 1 症例 1 側の検討と同様で, 左右は検討してあるが，左右を含め た 1 症例での出現率を示していない. そのため, やはり 低率になると考える.

以上より, 副耳下腺の出現率は $20 \sim 35 \%$ との報告が 多く, 藤ら ${ }^{8)}$ 10) の報告のみ $55 \%$ を超える高値ではある が, 症例数や検討方法, 出現率の算出法などから, 藤 ら ${ }^{8)}$ １0）の值は信頼性のある数值としてよいと考える. 正確な出現率を算出するためには，副耳下腺の同定方法 を統一し, 副耳下腺の出現率の定義を明確にする必要が あると考える。

2. 副耳下腺の出現部位 
副耳下腺は 1 つのみでなく複数認められることもあ

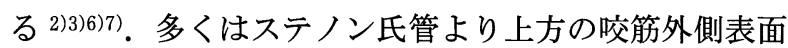
上で, 耳珠中央部から鼻翼と上口唇外側との中点を結ぶ 線の中 $1 / 3$ に存在している ${ }^{15)}$ ，そのため副耳下腺腫瘍は 煩部腫瘤として発症することが多く，耳鼻咽喉科だけで なく形成外科でも扱われることはまれでない 14171).

3. 副耳下腺腫瘍の発生率

耳下腺腫瘍に対する副耳下腺腫瘍の割合は $1 \sim 7$ $\left.\%{ }^{13)} \sim 15\right)$ と報告されている. 前述のように，副耳下腺の 出現率が明確にされていないため厳密なことはいえない が, $20 \sim 70 \%$ と考えたとしても, 副耳下腺から腫瘍が発 生する割合は，耳下腺に比べて低いといえる．組織学的 には副耳下腺は耳下腺と同様である78)14) が, 耳下腺より 容量が少ない分, 腫瘍発生母体が小さく, 腫瘍発生率が 低率になっていると考える。

\section{4. 副耳下腺腫瘍の組織分類}

耳下腺腫瘍のうち悪性の割合は約 $20 \%{ }^{18119)}$ とされるの に対し, 副耳下腺の場合 $30 \sim 50 \%{ }^{13314117) 20)}$ と報告され, 悪性腫瘍の頻度が高い，良性腫瘍は，耳下腺と同様で多 形腺腫が最も多く, 悪性腫瘍では粘表皮癌が耳下腺に比 ベて高い割合となっている.

5. 治療

耳下腺の場合と同様で完全摘出術が第 1 選択となる. 手術法として, 耳下腺手術に準じ $\mathrm{S}$ 字状切開で行ら拡大 法と，腫瘍直上切開で行ら方法とに意見が分かれてい る11141172121222．拡大法では，顔面神経本幹を同定した上 で，煩骨枝，煩筋枝を確認でき，顔面神経麻痺が回避で きる. 腫瘍直上切開は，皮膚切開を小さくできるが，顔 面神経やステノン氏管の確認が困難になりやすく, 煩部 中央に瘢痕が残る可能性があること，また局所再発の報 告 ${ }^{14)}$ もることなど，十分な検討の上，限られた症例に 用いるべきだと考える.

本症例は, 顔面煩部のほぼ中央に存在した副耳下腺か ら発生した多形腺腫であり, 完全摘出に際し顔面神経の 保存方法, 切除範囲など検討が必要であった。 副耳下腺 由来の腫瘍では共通した問題点と考える. 副耳下腺腫瘍 は，耳下腺腫瘍と比べて悪性の比率が高いことより，早 期の診断, 治療が必要となる. 本症例も初診時に経過観 察とせず，積極的に診断，治療に踏み切るべきであり， 煩部腫瘤を認めた場合，副耳下腺腫瘍の可能性を考える 必要があると考える.

\section{まとめ}

1）煩部に発生した副耳下腺由来の多形腺腫例を報告 した.

2）治療は，耳下腺手術に準じた $S$ 字状切開で，顔面神 経本幹を確認した上で神経を保存しながら腫瘍の完全摘 出を行った.

3）煩部正中に発生した腫瘤を認めた場合, 副耳下腺由 来の腫瘍も念頭に置く必要があると考えた。

な押, 本論文の要旨は, 第 14 回日本口腔・咽頭科学会総会 · 学術講演会（2001 年 9 月，東京）に扔いて口演した。

\section{参考文献}

1）小川㓐之輔：耳下腺の形態に就て。京都医誌 $15: 465$ ～ 485, 1918.

2）青 久雄, 岡田典雄 : 副耳下腺の解剖学的研究. 東京歯大 解剖業績集 $1: 1 \sim 5,1956$.

3）布施良三：耳下腺唾影像化関する知見補遗. 日耳鼻 $60: 805$ $\sim 818,1957$.

4) 北村 武：唾液腺造影法. 日耳鼻 $59: 655 \sim 661,1956$.

5）北村 武: 唾液腺造影法. 日耳鼻 $59: 1989 \sim 1995,1956$.

6）石島公德：日本人に於ける耳下腺の解剖学的研究 その 1 形態. 歯科学報 $58: 1 \sim 9,1958$.

7) Frommer $J$ : The human accessory parotid gland its incidence, nature, and significance. Oral Surg Oral Med Oral Pathol 43 : $671 \sim 676,1977$.

8）藤 英俊, 浜田法康, 大森忠雄：ヒ卜副耳下腺の解剖学的 研究. 福岡歯大会誌 $11: 38 \sim 43,1984$.

9）藤 英俊, 大森忠雄, 浜田法康, 他 : 七上副耳下腺の解剖 学的研究 (II).福岡菌大会誌 $14: 389 \sim 394,1988$.

10) Toh H, Kodama J, Fukuda J, et al. : Incidence and histology of human accessory parotid glands. Anat Rec $236: 586 \sim 590$, 1993.

11）遠藤芳彦, 水谷 伸, 二井一成: 副耳下腺多形腺腫の一例. 岩手県立病院医会誌 $37: 41 \sim 44,1997$.

12）上條雍彦: 口腔腺の解剖学. 口腔解剖学 第 5 巻 内臓学. $1404 \sim 1408$ 頁, アナトーム社, 東京, 1969.

13) Johnson FE and Spiro RH : Tumors arising in accessory parotid tissue. Am J Surg 138 : 576 578, 1979.

14）神保好夫, 营又 章, 野本猛美, 他 : 副耳下腺腫瘍の 2 手 術治験例。 日形会誌 $4: 326 \sim 332,1984$.

15) Perzik SL and White IL : Surgical management of preauricular tumors of the accessory parotid apparatus. Am J Surg 112:498 $\sim 503,1966$.

16）福田 博: 各種唾液腺疾患と唾影像. 唾液腺造影法の実際. $67 \sim 68$ 頁，（株）富士書院，札幌， 1990. 
17）小阪正明, 杉本 一, 清水隆司, 他：副耳下腺に生じた Mucoepidermoid carcinoma の 1例. 日形会誌 13:150 156, 1993.

18）村上 泰：耳下腺多形腺種の臨床特性. JOHNS $13: 7$ 12, 1997.

19）山下敏夫：唾液腺腫瘍 唾液腺の良性腫瘍. JOHNS 15 : $1895 \sim 1899,1999$.

20）安部治彦, 井上都子, 河原秀明 : 副耳下腺より発生したと 考えられるAdenocarcinomaの1例. 耳展 35:149〜153, 1992.
21）高橋光明, 高原 幹, 松井玲子, 他 : 副耳下腺腫瘍に対す る手術法. 頭頸部外科 $7: 1 \sim 6,1997$.

22）吉原俊雄:副耳下腺腫瘍の手術. 口咽科 14:219 223, 2002.

原稿受付 : 平成14年 4 月22日

原稿採択 : 平成14年 6 月 5 日

別刷請求先：萩池洋子

厂700-8558 岡山市鹿田町2-5-1

岡山大学大学院医歯学総合研究科耳鼻咽喉・頭頸部外 科学 